\title{
TRADISI SHALAWAT NGELIK DI KAMPUNG SANTRI MLANGI, SLEMAN, DIY
}

\author{
Nur Rokhim
}

UIN Sunan Kalijaga Yogyakarta

Email: arrokhim2649@gmail.com

\begin{abstract}
Abstrak
Tradisi shalawat ngelik adalah tradisi perayaan maulid Nabi Muhammad Saw., yang ada di Kampung Santri Mlangi, Sleman, DIY. Tradisi ini dilaksanakan pada puncak perayaan maulid nabi yakni tanggal 12 Rabiu'ul Awal di Masjid Pathok Negoro Mlangi. Penelitian ini mencoba mengungkap tradisi tersebut dan menganalis mengapa tradisi ini masih eksis hingga hari ini. Penelitian ini menggunakan dua teknik pengumpulan data, yakni studi pustaka dan lapangan. Pendekatan yang digunakan adalah pendekatan kualitatif dengan model etnografi. Penelitian ini dilakukan pada masyarakat Kampung Mlangi, Nogotirto Sleman. Penelitian ini menjelaskan sejarah singkat Kampung Santri Mlangi yang terbentuk atas prakarsa KH. Nur Iman Mlangi, kakak kandung Sultan Hamengkubuwono I. Penelitian ini juga mengungkap bahwa tradisi shalawat ngelik merupakan kebudayaan baru hasil persilangan antara kebudayaan Islam dan Jawa. Selain itu, penelitian ini juga mengungkap bahwa keberadaan belasan pesantren memiliki peran besar dalam menjaga keberlangsungan tradisi shalawat ngelik hingga kini. Santri-santri dari belasan pesantren tersebut, utamanya yang berasal dari desa Mlangi dan para pemuda di sana menjadi agen pelestari tradisi shalawat ngelik di kampung ini.

Kata kunci: Shalawat Ngelik, Mlangi, Masjid Pathok Negoro
\end{abstract}

\begin{abstract}
The tradition of ngelik prayer is a tradition of celebrating the birthday of the Prophet Muhammad., Which is in the Santri Village in Mlangi, Sleman, DIY. This tradition is carried out at the peak of the prophet's birthday celebration which is the 12th Rabiu'ul Awal at the Pathok Negoro Mosque in Mlangi. This study tries to uncover the tradition and analyze why this tradition still exists today. This study uses two data collection techniques, namely literature and field studies. The approach used is a qualitative approach with an ethnographic model. This research was conducted at the community of Kampung Mlangi, Nogotirto Sleman. This study explains the brief history of Santri Mlangi Village formed on the initiative of KH. Nur Iman Mlangi, sibling of Sultan Hamengkubuwono I. This study also revealed that the tradition of ngelik prayer is a new culture as a result of a cross between Islamic and Javanese cultures. In addition, this study also revealed that the existence of dozens of pesantren has a big role in maintaining the continuity of the tradition of ngelik prayer. The students from dozens of pesantren, mainly from Mlangi village and the young people there, are agents of preserving the tradition of ngelik prayer in this village.

Keywords: Shalawat Ngelik, Mlangi, Pathok Negoro Mosque
\end{abstract}

\section{A. PENDAhuluan}

Umat Islam Indonesia setiap tahun memiliki ritual tersendiri dalam menyambut hari lahir Nabi Muhammad Saw., yang jatuh pada tanggal 12 Rabiul Awwal. Ritual perayaan yang 
disebut dengan mauludan ${ }^{l}$ itu kental bernuansa tradisi lokal khas Indonesia. Berbagai daerah di Indonesia memiliki cara dan budaya tersendiri dalam mengekspresikan kegembiraan menyambut kelahiran nabi agung tersebut. Ambil contoh di Banten dan Cirebon misalnya, ribuan umat islam di sana mendatangi kompleks Masjid Agung Banten maupun Sunan Gunung Jati untuk melakukan ziarah makam wali dan sultan sekaligus mengikuti prosesi pemandian pusaka-pusaka keraton. Mereka juga dengan antusias mengambil bekas air cucian pusaka yang dipercaya mengandung barokah. ${ }^{2}$

Bagaimana dengan Yogyakarta dan Surakarta sebagai basis kerajaan Islam di Jawa? Di kedua daerah tersebut, perayaan maulid nabi dikenal dengan istilah sekaten. Kata sekaten sendiri berasal dari kata syahadatain yang berarti dua kalimat syahadat. Prosesi sekaten di awali dengan miyosgongso yaitu dikeluarkannya kedua perangkat gamelan KyaiNogoWilogo dan Kyai Guntur Madu dari tempat penyimpanannya di Bangsal Sri Manganti ke Bangsal Ponconiti yang terletak di Kemandungan Utara (Keben) tanggal 5 rabiul awal. Gamelan tersebut kemudian dibunyikan secara serentak selama tujuh hari berturut-turut hingga pada puncak acara sekaten tanggal 12 rabiul awwal. ${ }^{3}$

Pada kasus di Yogyakarta, perayaan maulid tidak hanya dirayakan oleh keraton saja. Beberapa daerah yang menjadi basis kaum santri juga merayakan maulid dengan tradisi yang berbeda, seperti misalnya Kampung Santri Mlangi, Sleman. Di kampung tersebut, perayaan maulid kental sekali dengan tradisi lokal. Perayaan maulid di sana dilaksanakan berbarengan dengan perayaan puncak sekaten di keraton. Salah satu perayaan maulid tersebut adalah shalawat ngelik.

Arus modernisasi dan globalisasi tidak membuat tradisi shalawatngelikini sirna. Sebaliknya, tradisi ini semakin eksis dan terus dijaga kelestariannya oleh masyarakat Kampung Santri Mlangi. Apa yang membuat tradisi ini terus bertahan di tengah globalisasi seperti saat ini? Fakta-fakta tersebut, bagi penulis adalah hal yang menarik untuk diteliti.

Dalam rangka membantu penulis dalam membahas tradisi shalawatngelik di Kampung

${ }^{1}$ Kata ini juga sangat populer di lingkungan masyarakat Indonesia, khususnya di kalangan etnis Jawa. Mereka menggunakan istilah bulan Mulud sebagai pengganti kata bulan Rabi'ul Awwal. Padahal sejatinya kata Maulud memiliki arti bayi atau seseorang yang dilahirkan. Maka penggunaan kata Maulud untuk memperingati hari lahir Rasulullah sudah bergeser dari makna aslinya. Meskipun demikian, KH. Said Aqil Siradj tidak mempermasalahkan penggunaan kata maulud. Kyai Said menegaskan bahwa baik mauludan maupun maulid semuanya benar. Menurut kiai asal Cirebon, Jawa Barat tersebut, ketika sebagian orang menyebut maulid nabi, berarti yang dihormati adalah hari kelahirannya. Sementara ketika menyebut maulud berarti isim maf'ul. Dengan demikian yang diperingati, dimuliakan adalah bayi yang dilahirkan, yaitu Nabi Muhammad Saw. Lihat Abdullah Alawi, "Maulid Nabi Atau Maulud Nabi? Ini Penjelasan Kyai Said" (December 3, 2016), accessed December 15, 2019, nu.or.id.

${ }^{2}$ Wasisto Raharjo Jati, “Tradisi, Sunnah \& Bid'ah: Analisa Barzanji Dalam Perspektif Cultural Studies,” el Harakah Vol.14 No.2 (2012): hlm. 226.

${ }^{3}$ Ibid., hlm. 227. 
Santri Mlangi, Sleman, DIY, maka disusunlah rumusan masalah sebagai berikut: bagaimana sejarah Kampung Mlangi, Sleman, DIY?, bagaimana tradisi shalawat ngelik di Kampung Mlangi, Sleman, DIY?, mengapa tradisi shalawat ngelik masih eksis di Kampung Mlangi, Sleman, DIY?

\section{B. TINJAUAN PUSTAKA}

Penulis menemukan beberapa penelitian yang berkaitan dengan Kampung Mlangi, hanya saja tidak ada yang spesifik membahas tentang tradisi shalawatngelik. Beberapa penelitian tersebut di antaranya adalah buku berjudul Sejarah Islam Lokal yang ditulis oleh Dosen Fakultas Adab UIN Sunan Kalijaga yakni Dr. Imam Muhsin, Dr. Zuhrotul Latifah dan Dr. Ali Sodiqin. Buku ini secara singkat membahas tentang dua kampung santri di DIY, Mlangi dan Wonokromo. Selain itu juga membahas tentang makam-makam Islam yang ada di DIY.

Selain buku tersebut, ada juga tulisan berjudul "Kyai Nur Iman dan Kampung Santri Mlangi; Menelisik Harmoni Integrasi Islam dengan Budaya Jawa-Keraton Mataram” karya Sukron Ma'mun yang dimuat di Jurnal Seneubok Lada Vol.2, No.2, Juli-Desember 2015. Karya tulis ini membahas peran Kiai Nurman dalam membangun masyarakat Mlangi yang religius dan setia pada tradisi. Pada tulisan ini, shalawat ngelik dibahas secara sekilas saja.

Terakhir, tulisan karya Zunly Nadia yang berjudul "Tradisi Maulid Pada Masyarakat Mlangi Yogyakarta”. Tulisan tersebut dimuat di Jurnal ESENSIA Vol XII No. 1 Januari 2011. Secara khusus, tulisan tersebuat membahas tentang perayaan maulid nabi yang dilaksanakan oleh masyarakat Mlangi, salah satunya shalawat ngelik. Hanya saja tidak fokus membahas shalawat ngelik.

\section{METODE PENELITIAN}

Penelitian ini merupakan penelitian lanjutan dari penelitian-penelitian sebelumnya. Sesuai tema yang penulis pilih, penelitian ini akan fokus terhadap tradisi shalawat ngelik yang masih eksis di Kampung Santri Mlangi Yogyakarta.

Penelitian ini adalah penelitian kebudayaan. Maryaeni dalam bukunya yang berjudul Metode Penelitian Kebudayaan, mengatakan bahwa penelitian kebudayaan adalah kegiatan membentuk dan mengabstraksikan pemahaman secara rasional empiris dari fenomena kebudayaan, baik itu terkait dengan konsepsi, nilai, kebiasaan, pola interaksi, asprek kesejarahan, biografi, teks media massa, film, pertunjukan (berkesenian), maupun berbagai bentuk fenomena budaya. Maryaeni menambahkan bahwa fenomena budaya beragam bentuknya seperti tulisan, rekaman lisan, perilaku, pembicaraan yang membuat konspesi, 
pemahaman, pendapat, ungkapan perasaan, angan-angan dan gambaran pengalaman kehidupan kemanusiaan. ${ }^{4}$

Kebudayaan merupakan segala macam bentuk gejala kemanusiaan, baik yang mengacu pada sikap, konsepsi, iideologi, perilaku, kebiasaan, karya kreatif dan sebagainya. Secara konkret, kebudayaan bisa mengacu pada adat istiada, bentuk-bentuk tradisi lisan, karya senin, bahasa, pola interaksi dan sebagainya. Dengan bahasa lain, kebudayaan adalah fakta kompleks yang memiliki kekhasan pada batas tertentu dan juga memiliki ciri yang universal. ${ }^{5}$

Pendekatan yang digunakan dalam penelitian ini adalah pendekatan kualitatif. Dengan menggunakan model etnografi. Etnografi adalah pekerjaan mendeskripsikan suatu kebudayaan. ${ }^{6}$ Dengan menggunakan pendekatan dan model tersebut, penulis hendak mendeskripsikan tradisi shalawat ngelik yang ada di Mlangi, Sleman, DIY. Dalam rangka mendapat gambaran yang jelas terkait kebudayaan tersebut, penulis telah melakukan studi pustaka dan juga studi lapangan.

Studi lapangan dilakukan di Desa Mlangi, Nogotirto, Sleman DIY. Penulis melakukan wawancara kepada tokoh di kampung tersebut. Setelah mendapatkan data wawancaran, penulis kemudian mengkolaborasikan data dari lapangan tersebut dengan sumber pustaka. Dari data-data tersebut, penulis kemudian menyusun dan menuliskannya.

\section{HASIL DAN PEMBAHASAN}

\section{Kiai Nur Iman dan Berdirinya Kampung Santri Mlangi}

Daerah Istimewa Yogyakarta (DIY) memiliki beberapa kampung santri, di antaranya adalah kampung santri Kauman, Jejeran, Plosokuning dan Mlangi. Tentu saja, penyebutan kampung santri tidak begitu gampang disematkan di kampung-kampung tersebut. Kampung Santri Mlangi (selanjutnya disebut Mlangi) misalnya, mendapatkan predikat santri karena di sini berdiri banyak sekali pesantren. Pengasuh Pesantren Aswaja Nusantara Mlangi Gus Tahfid mengungkapkan bahwa setidaknya ada 16-17 belasan pondok pesantren di Mlangi dengan total jumlah santri mencapai ribuan. ${ }^{7}$

Mlangi adalah sebuah padusunan kecil yang terletak di sebelah barat daya kota Yogyakarta. Jika dilihat dari google maps, jarak tempuh yang diperlukan untuk mencapai kampung ini-dengan menggunakan kendaraan roda doa-dari keraton Yogyakarta sekitar 19 menit. Kampung ini masuk dalam wilayah administrasi Desa Nogotirto, Kecamatan

\footnotetext{
${ }^{4}$ Maryaeni, Metode Penelitian Kebudayaan (Malang: Bumi Aksara, 2005), hlm. 23.

${ }^{5}$ Ibid., hlm. 5

${ }^{6}$ James P. Spradley, Metode Etnografi (Yogyakarta: Tiara Wacana, 2006), hlm. 6.

${ }^{7}$ Hasil Wawancara dengan Gus Tafid dikediamannya pada hari Rabu tanggal 27 Maret 2019.
} 


\section{Gamping, Kabupaten Sleman, Provinsi DI.Yogyakarta.}

Secara administratif, Mlangi ini terbagi menjadi 2 RW yang terbagi menjadi 8 RT. Di dusun ini kepala dusun, RT dan RW tidak terlalu mempunyai pengaruh kecuali hanya dalam hal tugas-tugas administratif. Sebagai daerah santri, kyai mempunyai peran dan pengaruh yang besar terhadap masyarakatnya, dari masalah tradisi sampai pada wilayah politik. ${ }^{8}$ Tentu saja, itu adalah hal yang wajar, mengingat para santri sangat menghormati dan ta'dzim kepada kiai.

Mlangi telah ditetapkan oleh Pemerintah Kabupaten Sleman menjadi salah satu desa wisata religi. Selain itu, Mlangi juga dikenal sebagai salah satu desa Pathok Negoro. ${ }^{9}$ Mlangi setidaknya memiliki lima modal sosial dan budaya yang dimiliki masyarakat setempat sehingga Pemkab Sleman menobatkannya sebagai desa wisata religi. Kelima modal sosial itu diantaranya adalah Masjid Pathok Negoro Mlangi, ekonomi kreatif, tradisi budaya, kesenian dan terakhir kuliner khas Mlangi. ${ }^{10}$ Berdasarkan pengamatan penulis, kelima modal sosial itu, hari ini masih dirawat dengan baik oleh masyarakat Mlangi.

Sebagai kampung santri, warga Mlangi menampilkan identitas keislaman penduduk dengan alamiah alias tidak dibuat-buat atau hanya untuk sekedareksis saja. Hal itu dapat dilihat dari gaya berpakaian mereka. Para lelaki di Mlangi, terbiasa memakai sarung, baju muslim, dan peci meskipun tidak hendak pergi ke masjid. Selain itu, sebagian besar-kalau tidak dikatakan semua-perempuan di Mlangi mengenakan jilbab, baik di dalam maupun di luar rumah. ${ }^{11}$ Pemandangan khas santri seperti itu banyak ditemui di lingkungan pesantren di berbagai tempat di Indonesia. Apalagi, sarung dan kopiah sangat identik sekali dengan santri sejak era penjajahan. Warga Mlangi yang dikenal sebagai kaum santri, lalu mengadopsi tradisi berpakaian ala santri tersebut menjadi gaya hidup keseharian mereka.

Sudah barang tentu, penulis berpandangan bahwa fakta kampung santri Mlangi yang demikian tidak terjadi ujug-ujug begitu saja. Ada proses panjang yang memakan waktu ratusan tahun hingga menghasilkan Mlangi sebagaimana yang dikenal hari ini. Mlangi memiliki sejarah panjang dan ketika berbicara tentang sejarah Mlangi, tentu tidak pernah lepas dari sosok tokoh kharismatik bernama KH. Nur Iman Mlangi.

\footnotetext{
${ }^{8}$ Zunly Nadia, "Tradisi Maulid Pada Masyarakat Mlangi Yogyakarta,” ESENSIA Vol. XII, No. 1 (January 2011): hlm. 370 .

${ }^{9}$ M. Jadul Maula, ed., Ngesuhi Deso Sak Kukuban: Lokalitas, Pluralisme, Modal Sosial Demokrasi (Yogyakarta: LKiS, 2001), hlm. 146.

${ }^{10}$ Kendi Setiawan, "Mengunjungi Desa Wisata Religi Mlangi” (July 27, 2018), accessed December 15, 2019, nu.or.id. Edisi Khusus

${ }^{11}$ Ida Farida, "Melongok Nuansa Islami Di Dusun Mlangi," Koran Media Indonesia, August 10, 2010,
} 
KH. Nur Iman (selanjutnya disebut Kiai Nur Iman) adalah tokoh penting dalam sejarah berdirinya Mlangi. Ia seorang kiai sekaligus seorang sufi dan mursyid thariqah naqsyabandiyah. ${ }^{12}$ Ia dikenal sebagai dai yang memiliki darah bangsawan Mataram. Ayahnya seorang Raja Mataram bergelar Amangkurat 1V. Sebelum menjadi raja, ayahnya yang memiliki nama kecil Raden Mas (RM) Suryo Putro alias Sunan Mangkurat Jawi tinggal dan menuntut ilmu di Pesantren Gedangan di bawah asuhan Kyai Abdullah Muhsin. ${ }^{13}$ Di pesantren itulah, RM Suryo Putro menyamar menjadi rakyat biasa dan dengan leluasa mengaji dengan Kyai Abdullah tanpa ada yang mengenali statusnya sebagai bangsawan.

Kepergian RM Suryo Putro dari keraton tidak terlepas dari kekacauan yang ditimbulkan oleh penjajah Belanda di internal keraton Mataram. Sebagaimana diketahui, sejak Belanda melalui VOC membantu meredam pemberontakan Trunojoyo (1670-an), mereka mendapatkan kompensasi yang besar. Mereka mengendalikan mekanisme pengangkatan raja dan pergantian tahta Mataram. VOC menjadi pemasok senjata dan personel militer bagi calon raja yang meminta bantuan kepadanya. ${ }^{14}$ Peran VOC tersebut mirip dengan peran para tentara Turki yang mengendalikan pemerintahan Abbasiyah sejak era Khalifah alMu'tashim. ${ }^{15}$

RM Suryo Putro dipanggil pulang ke Keraton Mataram Surakarta ketika tindakan VOC semakin tidak terkendali di lingkungan Keraton. RM Suryo Putro kembali ke Mataram dengan meninggalkan seorang istri yang sedang mengandung. Bayi yang masih di dalam kandungan itulah yang kemudian diberi nama Raden Sandiyo alias KGPH Kertosuro atau yang lebih dikenal sebagai Kyai Nur Iman Mlangi. Setelah berhasil mengatasi kekacauan, RM Suryo Putro diangkat menjadi Amangkurat IV.

Raden Sandiyo kecil tumbuh dalam asuhan Kyai Abdullah Muhsin. Setelah beranjak remaja, ia dipanggil ke Keraton Kartasura. Setibanya di sana, ia dianugerahi gelar Bendara Pangeran Hangabei ${ }^{16}$ (BPH) dan dinikahkan dengan putri dari Suryo Mataram. Ketika terjadi perebutan kekuasaan di istana dan geger pecinan tahun 1740-1743 M, ia memilih menjauh dan menghindar dari konflik. Ia pergi berdakwah ke arah barat (Kulonprogo). ${ }^{17}$ Sikapnya

\footnotetext{
${ }^{12}$ Irwan Masduqi, Suluk Sufi Ulama Karaton Yogyakarta: Ajaran Kyai Nur Iman (Yogyakarta: Assalafiyah Press, 2011), hlm. 20.

${ }^{13}$ Sukron Ma'mun, “Kyai Nur Iman Dan Kampung Santri Mlangi; Menelisik Harmoni Integrasi Islam Dengan Budaya Jawa-Keraton Mataram,” Jurnal Seuneubok Lada Vol. 2, No.2 (July-December 2015): hlm. 101.

${ }^{14}$ Daliman, Islamisasi Dan Perkembangan Kerajaan-Kerajaan Islam Di Indonesia (Yogyakarta: Obak, 2012), hlm. 177.

${ }^{15}$ M. Abdul Karim, Sejarah Pemikiran Dan Peradaban Islam (Yogyakarta: Bagaskara, 2017), hlm. 163.

${ }^{16}$ Imam Muhsin dkk, Sejarah Islam Lokal (Yogyakarta: Sukses Offset, 2008), hlm. 32. 2016): hlm. 34 .

${ }^{17}$ Indah Abror, "Aktualisasi Nilai-Nilai Budaya Masjid Pathok Negoro," ESENSIA Vol. 17, No.1 (April
} 
yang tidak suka dengan hiruk pikuk dunia perpolitikan membuatnya memilih jalur dakwah.

Sandiyo yang kemudian dikenal dengan nama Nur Iman baru dicari oleh adik-adiknya setelah perjanjian Giyanti tahun 1755. Ia bertemu dengan salah satu adiknya yang bernama Sujana atau Pangeran Mangkubumi. Oleh adiknya, ia diajak pulang ke keraton. Bersamaan dengan penobatan Pangeran Mangkubumi menjadi Raja Pertama Mataram dengan gelar Sultan Hamengkubuwono I, ia dianugerahi tanah perdikan (bebas pajak) untuk ditempati. Tanah perdikan itu kemudian dikenal sebagai tempat mulangi (mengajar). ${ }^{18}$ Sebab, di tanah perdikan tersebut, Kyai Nur Iman mulangi masyarakat ilmu agama. Lama kelamaan kosakata mulangi berubah menjadi Mlangi hingga hari ini. ${ }^{19}$

\section{Tradisi Shalawat Ngelikdi Kampung Santri Mlangi}

Sebagai kampung santri, masyarakat Mlangi sudah terbiasa menggelar acara shalawatan dalam berbagai event, seperti acara kelahiran anak, khitanan, nikahan dan sebagainya. Khusus dalam perayaan maulid pada tanggal 12 Rabiul Awwal, pembacaan maulid diselenggarakan dengan sangat meriah. Masyarakat menyelenggarakan perayaan akbar menyambut hari lahir Nabi Muhammad Saw itu di Masjid Pathok Negoro Mlangi. Pada hari perayaan, masyarakat Mlangi tumplek blek di Masjid Pathok Negoro Mlangi.

Seorang dosen Institut Agama Islam Negeri (IAIN) Surakarta, Abdoel Halim menggambarkan dengan apik proses perayaan maulid di Mlangi ${ }^{20}$, khususnya acara shalawat ngelik yang juga disebut gladden yang digelar dari pukul 07.00-13.30 WIB. Abdoel Halim memulai kisahnya dengan menjelaskan bahwa di Mlangi perayaan maulid Nabi diadakan dengan melakukan pembacaan Maulid Syaraful Anam. Cara membaca shalawat ini pun menurutnya tergolong unik, yakni menggunakan teknik suara dalam yang memekik tinggi dan disertai dengan hentakan tepukan tangan yang menunjukkan kegembiraan. Barangkali karena itulah, shalawatan ini dinamai shalawat ngelik. Bagi yang belum terbiasa, tidak akan paham dengan yang sedang dibaca. Bahkan, sebagian masyarakat asli Mlangi ada yang tidak paham.

Senada dengan Abdoel Halim, salah satu pemuda Mlangi Ficky Taufiqurrahman bercerita shalawat ngelik ini dilantunkan dengan nada tinggi dengan tempo yang beragam, mulai dari tempo pelan sampai cepat. Jadi memang tidak semua orang bisa melantukan shalawat ini. Bahkan ada anggapan bahwa orang yang bisa melantunkan shalawat ini bersifat genetis.

\footnotetext{
${ }^{18}$ Muhsin, Sejarah Islam Lokal, hlm. 34.

${ }^{19}$ Ibid., hlm. 69.

${ }^{20}$ Abdoel Halim, "Di Mlangi, Kau Akan Temukan Mauludan Yang Eksotis," bangkitmedia.com (November
} 21, 2018), diakses pada 15 Desember 2019 
Artinya, jika seseorang bisa shalawatan ngelik, maka keturunannya kelak bisa melantunkan shalawat ini juga. ${ }^{21}$

Selain dengan nada yang tinggi, pembacaan shalawat ini tidak dengan nada dan logat sebagaimana umumnya membaca teks bahasa arab. Pembacaan shalawat ini mirip dengan tembang-tembang Jawa khas keraton. Dalam istilah orang hindu, disebut uro-uro yaitu pembaca meliuk-liukkan suara seperti membaca lagu. ${ }^{22}$ Nada yang dilantunkan seperti bunyi tembang-tembang jawa pada umumnya.

Ketika para lelaki shalawatan ngelik di Masjid Pathoknegoro, para ibu-ibu sibuk menyiapkan berkat atau nasi lengkap dengan lauk pauk yang akan dibawa ke masjid. Hal itu menurut Abdoel Halim sudah menjadi kesepakatan umum, bahwa masing-masing warga membuat bingkisan sebanyak dan sebagus yang mereka mampu untuk dikumpulkan di masjid dan dibagi-bagikan ke masyarakat yang hadir usai acara.

Selain itu, Gus Tafied mengatakan bahwa berkat dalam acara shalawat ngelik dimaknai warga Mlangi sebagai sedekah di hari kelahiran Nabi Muhammad Saw. Sedekah tersebut dilakukan dalam rangka bergembira menyambut lahirnya Nabi Muhammad Saw.

Biasanya, orang-orang berlomba-lomba untuk membuat berkat sebaik mungkin, karena berkat yang terbaik akan diberikan kepada para kyai yang notebene menjadi panutan masyarakat Mlangi. Berkat tidak hanya berisi nasi lengkap dengan sayur dan lauk pauknya tetapi juga berisi hadiah bahkan terkadang berisi uang didalamnya. Hadiah yang diberikan juga bermacam-macam, mulai dari baju, alat rumah tangga seperti termos, panci, hingga majic com, sedangkan uang di dalam berkat tersebut jumlahnya berkisar antara 50.000, 100.000 hingga 200.000. Bagi masyarakat Mlangi, adalah suatu kebanggan tersendiri jika berkatnya diberikan kepada kyai. ${ }^{23}$ Bagi yang berkatnya diberikan kepada kyai, berharap hal itu akan mendatangkan berkah bagi keluarganya.

Berikut ini salah satu petikan terjemahan dari kitab maulid Syaraful Anam yang dibaca dalam perayaan maulid nabi

Ya Allah, dengan kesucian Nabi Muhammad yang mulia dan para keluarga serta para sahabat yang menempuh jalannya yang lurus, jadikan kami sebagai umat pilihannya; tutuplah aib kami dengan sepercik kesuciannya; kumpulkan kami dalam golongannya;

\footnotetext{
Maret 2019

${ }^{21}$ Hasil wawancara dengan Ficky Taufiqurrahman di Masjid Pathok Negoro Mlangi pada Rabu tanggal 27

${ }^{22}$ Ma'mun, "Kyai Nur Iman Dan Kampung Santri Mlangi; Menelisik Harmoni Integrasi Islam Dengan Budaya Jawa-Keraton Mataram,” hlm. 104.

${ }^{23}$ Nadia, “Tradisi Maulid Pada Masyarakat Mlangi Yogyakarta,” hlm. 374.
} 
Tamaddun: Jurnal Kebudayaan dan Sastra Islam, Vol. 20 No. 1, 2020 |

jadikan lisan kami selalu memuji dan menegakkan sunnahnya; hidupkan kami dengan berpegang teguh pada ketaatan dan cinta kepadanya; wafatkan kami dalam keadaan berpegang teguh pada sunnah dan golongannya. Ya Allah, masukkan kami ke surga bersamanya karena ia adalah orang pertama masuk surga; tempatkan kami dalam istana surga karena ialah yang pertama menempoatinya; welasi kami karenanya di hari semua makhluk meminta syafaatnya yang kemudian engkau rahmati mereka karena syafaatnya. ${ }^{24}$

\section{Akulturasi dalam Tradisi Sholawat Ngelik}

Berdasarkan penjelasan tentang tradisi shalawat ngelik di kampung Mlangi, Sleman, DI Yogyakarta, Penulis menganalisis, bahwa telah terjadi kontak budaya antara budaya lokal Mlangi (Jawa) dan budaya Islam.

Perayaan maulid nabi Muhammad adalah tradisi Islam. Perayaan ini pertama kali diperkenalkan oleh Dinasti Fatimiyah yang berkuasa di Mesir tahun 909-1171 M. Dinasti ini mewajibkan masyarakat menyenandungkan pujian kepada Nabi Muhammad Saw., saat perayaan maulid nabi tiba pada bulan Rabi'ul Awal. Bagi khalifah, tradisi pujian ini diresmikan sebagai tradisi negara maupun sebagai legitimasi politis bahwa dinasti inilah yang merupakan kekhalifahan Islam berdasar garis keturunan nabi. ${ }^{25}$

Ketika Dinasti Fatimiyah runtuh digantikan dengan Dinasti Ayyubiyah, tradisi perayaan maulid nabi tetap dilestarikan. Setelah dipopulerkan oleh AbûSa'id al-Kakburi, gubernur wilayah Irbil di masa pemerintahan Salahudin al Ayyubi(1250-1260), peringatan maulid berubah menjadi sebuah perayaan yang diselenggarakan hampir di setiap kawasan dunia Islam. Selain dalam rangka menyambut kelahiran Nabi Muhammad Saw., peringatan maulid diselenggarakan untuk memperkukuh semangat keagamaan umat Islam yang sedang menghadapi ancaman tentara Salib (Crusaders) dari Eropa. Perlu diketahui bahwa suasana perang yang dialami komunitas Muslim telah menimbulkan kegalauan batin, hingga mereka memerlukan simbol-simbol keagamaan yang mampu meredam kegundahan tersebut. ${ }^{26}$

Salahudin al Ayyubi beranggapan bahwa tradisi menyanyikan pujian kepada Rasulullah Saw., dapat mempertebal keimanan dan ketakwaan kepada rasul. Selain itu, dapat juga menambah semangat juang dalam Perang Salib III melawan Pasukan Nasrani dari Eropa yang berupaya menduduki Yerusalem. Salahudin juga lah yang menyelenggarakan

\footnotetext{
${ }^{24}$ Halim, "Di Mlangi, Kau Akan Temukan Mauludan Yang Eksotis."

${ }^{25}$ Jati, “Tradisi, Sunnah \& Bid'ah: Analisa Barzanji Dalam Perspektif Cultural Studies,” hlm. 229.

${ }^{26}$ Thoha Hamim, hlm 237
} 
sayembara penulisan riwayat Nabi beserta puji-pujian bagi Nabi dengan bahasa yang seindah mungkin. Dalam sayembara tersebut, juara pertama adalah Syaikh Ja`far al Barzanji dengan hasil karyanya yang dikenal Iqd al Jawahir (kalung permata) atau familiar dengan sebutan Kitab Barzanji ${ }^{27}$

Tradisi perayaan maulid nabi kemudian masuk ke Indonesia dibawa oleh para penyebar Islam dari Persia yang pernah tinggal di Gujarat. Pendapat lain mengatakan bahwa tradisi ini dibawa oleh ulama bermahzabSyafi'i terutama Syekh Maulana Malik Ibrahim yang dikenal gurunya Walisongo. Syekh Maulana Malik Ibrahim menyebarkan Islam di daerah pesisir Sumatera Timur maupun Pantai Utara Jawa dikenal amat toleran dan moderat dalam berdakwah. Seni barzanji kemudian turut menginsipirasi Sunan Kalijaga untuk menciptakan lagu li-ilir maupun tomboati yang sangat familiar di kalangan pesantren dalam melakukan dakwahnya di kawasan pedalaman Jawa. ${ }^{28}$

Sementara itu, seni pembacaan kitab Maulid SyarafulAnam dengan menggunakan langgam atau nada seperti nyanyian tembang jawa macapat adalah budaya lokal Mlangi yang dulunya merupakan tanah perdikan Keraton Ngayogyakarta. Sebagai tanah perdikan, tentu saja, tanah ini memiliki hubungan yang erat dengan keraton. Apalagi, Kiai Nur Iman Mlangi sebagai "penguasa” di Mlangi merupakan kakak dari Sultan HB I.

Berbicara soal tembang macapat, secara historis, menurut Poerbatjaraka tembang macapat muncul sejak zaman kerajaan Demak, kemudian berkembang ke Pajang, Mataram, Surakarta, dan Yogyakarta. Pujangga terakhir yang menggunakan macapat adalah R.Ng Ranggawarsita. ${ }^{29}$ Tembang macapat sendiri terdiri atas 11 tembang, yakni maskumambang, mijil, sinom, kinanthi, asmaradhana, gambuh, dhandanggula, durma, pangkur, megatruh, pocung.

Dari penjelasan tersebut, jelas dapat dipahami bahwa tradisi perayaan maulid nabi adalah kebudayaan yang berasal dari Islam sementara pembacaan kitab maulid Syaraful Anam dengan menggunakan langgam jawa macapatan adalah tradisi Jawa. Dengan demikian, pada perayaan maulid nabi dengan bentuk shalawat ngelik terjadi akulturasi dua budaya, yakni budaya Islam dan budaya jawa. Dalam shalawat ngelik, dua budaya ini bisa bersatu tanpa menghilangkan identitas budaya asli Jawa yang ada di Mlangi. Tentu saja, dalam kasus ini, proses akulturasi yang terjadi adalah proses akulturasi secara damai, bukan dengan kekerasan.

\footnotetext{
${ }^{27}$ Jati, “Tradisi, Sunnah \& Bid'ah: Analisa Barzanji Dalam Perspektif Cultural Studies,” hlm. 230.

${ }^{28}$ Ibid., hlm. 231.

${ }^{29}$ Suwardi, “Wawasan Hidup Jawa Dalam Tembang Macapat,” Diksi Vol. 13, No. 5 (May 1997): hlm. 19.
} 
Pertanyaan selanjutnya, kemudian, mengapa tradisi perayaan maulid nabi dalam bentuk shalawat ngelik ini bisa bertahan dan diterima oleh masyarakat Mlangi? Hal ini karena peran pesantren-pesantren yang ada di Mlangi. Sebagaimana telah disebutkan di awal, bahwa di Mlangi berdiri banyak pondok pesantren dengan total jumlah santri mencapai ribuan. Pesantren-pesantren tersebut dengan para kyainya menjadi aktor penting dalam proses terbentuknya masyarakat Mlangi hari ini. Apalagi pesantren-pesantren tersebut sudah berdiri sejak lama. Tercatat, pesantren tertua yang hari ini masih berdiri di Mlangi dan berkembang dengan pesat adalah pesantren As-Salafiyah yang didirikan oleh Kiai Masduqi tahun 1936.

Gus Dur menyebut pesantren sebagai subkultur karena memiliki keunikan tersendiri dalam beberapa aspek, yakni cara hidup yang dianut, pandangan hidup dan tata nilai yang diikuti serta memiliki hierarki kekuasaan intern tersendiri yang ditaati sepenuhnya. ${ }^{30}$ Dengan pola kehidupannya yang unik tersebut, pesantren mampu bertahan berabad-abad lamanya serta mampu melakukan perubahan sosial bagi masyarakat di lingkungan sekitar pesantren.

Gus Dur menjelaskan bahwa pengaruh utama yang dimiliki pesantren atas kehidupan masyarakat terletak pada hubungan perorangan yang menembus segala hambatan yang diakibatkan oleh pebedaan strata yang ada di masyarakat. Hubungan tersebut menurut Gus Dur memiliki dua tugas yakni mengatur bimbingan spiritual dari pihak pesantren kepada masyarakat dalam hal perdata agama (perkawinan, waris, dll) dan soal ibadat ritual serta pemeliharaan materil-finansial oleh masyarakat atas pesantren (dalam bentuk pengumpulan dana dll). Bagi anggota masyarakat luar, kehidupan pesantren merupakan gambaran ideal yang tidak mungkin dapat direalisir dalam kehidupanya: dengan demikian pesantren adalah tempat yang dapat memberikan kekuatan spiritual kepadanya dalam saat-saat tertentu. Di samping itu, bagi pesantren yang menjadi pusat gerakan (tasawuf), terdapat daya tarik dalam kedudukan sebagai pusat gerakan. Tidak jarang pula faktor kharismatik yang dimiliki seorang kyai merupakan daya tarik yang kuat pula. ${ }^{31}$

Apa yang disampaikan Gus Dur tersebut adalah bentuk nyata bahwa pesantren memiliki pengaruh yang besar dalam mempengaruhi kehidupan sosial masyarakat. Pesantren menjadi tempat rujukan masyarakat menanyakan hal-hal yang berkaitan dengan bab agama. Apalagi jika kyai pengasuh pondok pesantren memiliki kharisma yang tinggi, maka sudah barang tentu pesantren menjadi pusat perubahan sosial bagi lingkungan di sekitarnya.

Sebagaimana diketahui, bahwa di pesantren-pesantren, tradisi pembacaan shalawat dalam

\footnotetext{
${ }^{30}$ Abdurrahman Wahid, "Pesantren Sebagai Subkultur", dalam Menggerakkan Tradisi: Esai-Esai Pesantren, Cet. 1. (Yogyakarta: LKiS, 2001), hlm. 9.

${ }^{31}$ Ibid., 32-33
} 
menyambut hari lahir Nabi Muhammad Saw., masih lestari hingga kini. Santri-santri lulusan pondok di Mlangi kemudian ketika keluar, tetap melestarikan budaya tersebut. Sementara di Mlangi sendiri, masih ada tradisi shalawatanngelik yang menggunakan langgam Jawa. Tentu saja, para santri lalu menjadi agen yang terus melestarikan tradisi tersebut. Sebab, tradisi pembacaan kitab SyarafulAnam degan menggunakan langgam jawa sama sekali tidak bertentangan dengan syariat Islam.

Peran pesantren terhadap masih eksisnya shalawat ngelik di Mlangi juga terlihat ketika pesantren mengerahkan santri-santrinya untuk ikut hadir dalam acara Peringatan maulid Nabi di Masjid PathokNegoro Mlangi. Pada acara peringatan tersebut, shalawat dibacakan dengan menggunakan langgam Jawa. Dengan demikian, secara tidak langsung, pesantren berperan dalam mengenalkan tradisi shalawat ngelik kepada para santri-santrinya, terutama santri yang berasal dari luar Mlangi.

Selain itu, shalawat ngelik masih bisa eksis hingga hari ini di kampung Mlangi adalah lantaran para pemuda di sana tidak malu untuk melestarikan shalawatberlanggam jawa ini. Menurut penuturan Gus Tafied, para pemuda di Mlangi rutin menggelar shalawat ngelik setiap 35 hari sekali atau selapanan. ${ }^{32}$ Selain sebagai ajang latihan, rutinan tersebut merupakan salah satu ihtiar dalam rangka melestarikan shalawat ngelik di bumi Mlangi.

\section{E. KESIMPULAN}

Kampung Mlangi adalah kampung santri yang terletak di bagian barat daya dari Kota Yogyakarta. Kampung ini masuk ke dalam administrasi Desa Nogotirto, Kecamatan Gamping, Kabupaten Sleman, Provinsi D.I Yogyakarta. Sebagai kampung santri, di Mlangi terdapat belasan pondok pesantren yang total keseluruhan santrinya berjumlah ribuan. Sejarah Mlangi tidak lepas dari sosok kharismatik yang makamnya juga berada di Mlangi, tepatnya di Masjid Pathoknegoro Mlangi, yakni Kyai Nur Iman. Ia adalah seorang ulama yang memiliki darah biru keraton Ngayogyokarto Hadiningrat. Mlangi hari ini, dulunya adalah daerah perdikan yang diberikan Keraton Ngayogyokarto Hadiningrat kepada Kyai Nur Iman. Di daerah tersebut, Kyai Nur Iman mulangi atau mengajar ngaji masyarakat setempat. Lama-kelamaan kata mulangi berubah menjadi Mlangi yang kemudian menjadi nama daerah tersebut hingga hari ini.

Kampung Mlangi menjadi tempat berkembangnya tradisi masyarakat, salah satunya tradisi perayaan maulid Nabi dalam bentuk shalawat ngelik. Shalawat ngelik adalah tradisi pembacaan shalawat dengan nada khas tembang-tembang Jawa dengan beragam tempo.

\footnotetext{
${ }^{32}$ Hasil Wawancara dengan Gus Tafid dikediamannya pada hari Rabu tanggal 27 Maret 2019
} 
Tradisi perayaan maulid nabi di Mlangi yang berupa shalawat ngelik merupakan hasil proses akulturasi secara damai antara budaya Islam dan budaya Jawa yang menyatu tanpa menghilangkan kebudayaan asli Jawa. Penyatuan dua budaya ini sehingga menjadi dalam bentuk shalawat ngelik, mampu bertahan hingga hari ini karena sokongan pesantrenpesantren yang ada di Mlangi. Pesantren sebagai bagian penting dalam masyarakat Mlangi memiliki peran vital menjaga dan melestarikan tradisi shalawat ngelik yang ada di Mlangi. Tentunya dengan catatan tradisi tersebut tidak bertentangan dengan pokok-pokok ajaran Islam. Selain itu, anak-anak muda di Mlangi juga tidak malu untuk melestarikan shalawat ngelik.

\section{DAFTAR PUSTAKA}

Abror, Indah. “Aktualisasi Nilai-Nilai Budaya Masjid Pathok Negoro.” ESENSIA Vol. 17, No.1 (April 2016).

Alawi, Abdullah. "Maulid Nabi Atau Maulud Nabi? Ini Penjelasan Kyai Said" (December 3, 2016). Accessed December 15, 2019. nu.or.id.

Daliman. Islamisasi Dan Perkembangan Kerajaan-Kerajaan Islam Di Indonesia. Yogyakarta: Obak, 2012.

Farida, Ida. "Melongok Nuansa Islami Di Dusun Mlangi." Koran Media Indonesia, August 10, 2010, Edisi Khusus edition.

Halim, Abdoel. "Di Mlangi, Kau Akan Temukan Mauludan Yang Eksotis." bangkitmedia.com (November 21, 2018).

Jati, Wasisto Raharjo. "Tradisi, Sunnah \& Bid'ah: Analisa Barzanji Dalam Perspektif Cultural Studies.” el Harakah Vol.14 No.2 (2012): 226.

Karim, M. Abdul. Sejarah Pemikiran Dan Peradaban Islam. Yogyakarta: Bagaskara, 2017.

Ma'mun, Sukron. "Kyai Nur Iman Dan Kampung Santri Mlangi; Menelisik Harmoni Integrasi Islam Dengan Budaya Jawa-Keraton Mataram." Jurnal Seuneubok Lada Vol. 2, No.2 (December 2015).

Maryaeni. Metode Penelitian Kebudayaan. Malang: Bumi Aksara, 2005.

Masduqi, Irwan. Suluk Sufi Ulama Karaton Yogyakarta: Ajaran Kyai Nur Iman. Yogyakarta: Assalafiyah Press, 2011.

Maula, M. Jadul, ed. Ngesuhi Deso Sak Kukuban: Lokalitas, Pluralisme, Modal Sosial Demokrasi. Yogyakarta: LKiS, 2001.

Muhsin, Imam. Sejarah Islam Lokal. Yogyakarta: Sukses Offset, 2008.

Nadia, Zunly. "Tradisi Maulid Pada Masyarakat Mlangi Yogyakarta.” ESENSIA Vol. XII, No. 1 (January 2011). 
Tamaddun: Jurnal Kebudayaan dan Sastra Islam, Vol. 20 No. 1, 2020|

Setiawan, Kendi. "Mengunjungi Desa Wisata Religi Mlangi" (July 27, 2018). Accessed December 15, 2019. nu.or.id.

Spradley, James P. Metode Etnografi. Yogyakarta: Tiara Wacana, 2006.

Suwardi. “Wawasan Hidup Jawa Dalam Tembang Macapat.” Diksi Vol. 13, No. 5 (May 1997).

Wahid, Abdurrahman. Menggerakkan Tradisi: Esai-Esai Pesantren. Cet. 1. Yogyakarta: LKis, 2001. 